\title{
ABCA1 Gene
}

National Cancer Institute

\section{Source}

National Cancer Institute. ABCA1 Gene. NCI Thesaurus. Code C116408.

This gene plays a role in intracellular cholesterol transport. 